\title{
Wspólnoty pamięci lokalnej i narodowej. Kilka uwag o ich zbiorowym wytwarzaniu à la polonaise
}

Joanna Kurczewska

TEKSTY DRUGIE 2016, NR 6, S. 30-51

DOI: $10.18318 /$ td.2016.6.3

wój esej - określiłabym go mianem socjologiczno-instytucjonalnego - poświęcę problemom wytwarzania wspólnot pamięci: lokalnej oraz narodowej. Pragnę zwrócić uwagę na podmioty pamięci, na ich aktywność w przestrzeni społecznej III Rzeczypospolitej. Uważam, że zorganizowane wytwarzanie pamięci ma istotne znaczenie strategiczne dla rzetelnego orzekania o specyfice i meandrach polskiej pamięci "tu i teraz".

Moim zdaniem warto nieustannie podkreślać rolę ludzi, którzy tworzą te wspólnoty i uczestniczą w procesie różnicowania, uspołecznienia, a zwłaszcza jednej z jej form - mocnej instytucjonalizacji wspólnot lokalnych i narodowych - całościowej lub cząstkowej w postaci stowarzyszeń, klubów, fundacji, organizacji społecznych czy inicjatyw obywatelskich. Innymi słowy, chcę zaznaczyć, że nie tylko ludzie są istotni, a także tworzone przez nich różne formy organizacyjne w różnych momentach i miejscach społecznych, politycznych i kulturowych.

Stawiając w centrum uwagi problem budowania i podtrzymywania wspólnot pamięci, trzeba koniecznie
Joanna Kurczewska - socjolog i historyk idei, pracuje w Instytucie Filozofii i Socjologii PAN. Zajmuje się socjologią historyczną, socjologią teoretyczną, historią myśli społecznej, pograniczem socjologii kultury i socjologii polityki. Szczególnie interesują ją zagadnienia różnych form wspólnotowości, zmiany społecznej i relacji między tradycją a nowoczesnością narodową. Wydawała tomy "Oblicza lokalności", ostatnio opublikowała artykuł Kreacje małych ojczyzn ("Societas Communitas" 2015, $n r 1 / 2$ ). 
pytać o emocje, nie tylko dlatego, że są one coraz ważniejsze w każdej postaci dyskursu publicznego współczesnych społeczeństw i narodów, ale także dlatego, że organizacje czynią je szkołami intensywnego przeżywania więzi międzyludzkich.

Warto przypomnieć, że wspólnoty lokalne i narodowe, bez względu na to, jaki ich typ mamy na uwadze, są wspólnotami e m o cj o n al ny mi1'. (Rodziny, sąsiedzi, grupy towarzyskie czy wspólnoty parafialne są "wytwórniami” różnego rodzaju uczuć łączących i dzielących ludzi, środowiska czy organizacje). Właśnie one - i to bez względu na to, czy są to wspólnoty tradycyjne czy sieciowe, wyobrażone czy realne - są nastawione na odczuwanie i wartościowanie więzi międzyludzkich, i to w taki sposób, że odnoszą się do szerokiego zakresu emocji pozytywnych i negatywnych.

Proponując spojrzenie na polską pamięć z perspektywy wspólnot, trzeba koniecznie ujawnić przyjęte $\mathrm{w}$ tym eseju podstawowe ustalenia teoretyczne. Dotyczą one zarówno charakteru socjologicznych badań stosunku Polaków do swojej przeszłości narodowej i lokalnej, jak i odnoszą się do prymarnych założeń aksjologicznych diagnozy polskiej rzeczywistości z ostatnich kilkudziesięciu lat.

Choć powinnam zacząć od diagnozy polskiej rzeczywistości, skupiając się na instytucjach, zacznę od dość krótkiej charakterystyki esencji badań socjologicznych. Tak chyba można postąpić, jeśli pragnie się mocno podkreślić rolę zinstytucjonalizowanych form wytwarzania socjologicznej wiedzy. Chciałabym zasygnalizować coś, co nazwę wycinankami socjologicznymi: są nimi generalizacje wywiedzione z bardzo bogatego i zróżnicowanego zasobu socjologicznych badań nad stosunkiem Polaków do przeszłości².

Warto pamiętać, że badania socjologiczne nad pamięcią mają naprawdę długą tradycję, sięgającą prac Stefana Czarnowskiego i jego uczniów. Podobnie jest też w przypadku jej badań empirycznych ilościowych i jakościowych;

1 Chodzi o koncepcję Barbary Rosenwein. Zob. B. Rosenwein Problems and Methods in the History of Emotions, "Passions in Context” 2010 vol. 1; tejże Emotional Communities in the Early Middle Ages, N.Y. Cornell University Press, Ithaca 2006.

2 P. Kwiatkowski Pamięć zbiorowa społeczeństwa polskiego w okresie transformacji, Wydawnictwo Naukowe Scholar, Warszawa 2008. Zob. B. Korzeniowski Transformacja pamięci. Przewartościowania w pamięci przeszłości a wybrane aspekty funkcjonowania dyskursu publicznego o przeszłości w Polsce po 1989 roku, Wydawnictwo PTPN, Poznań 2010; M. Kucia, M. Dutch-Dyngosz, M. Magierowski The Collective Memory of Auschwitz and the Second World War among Catholics in Poland. A Qualitative Study of Three Communities, "History and Memory” 2013 vol. 25 no. 2. 
datują się one na lata 6o. ubiegłego wieku³. (Badania empiryczne należały w okresie PRL-u do szczególnie wrażliwych na zmiany i klimaty polityczne i kulturowe. Były w środowiskach Polskiego Towarzystwa Socjologicznego, dość autonomicznej na te czasy organizacji, zaliczane do mało bezpiecznych...4).

Chciałabym przypomnieć najważniejsze ustalenia moich kolegów. Wyniki badań prowadzonych przez Andrzeja Szpocińskiego i Piotra Kwiatkowskiego oraz Barbarę Szacką wskazują, że w latach 9o. nastąpiła zmiana w organizacji uniwersum kultury w Polsce. W tych badaniach akcentowano, że uniwersum kulturowe klas niższych, a to właśnie ono ma wpływ na sposoby kształtowania strategii wobec przeszłości, jest zbudowane inaczej niż w klasach wyższych. W podsumowaniach podkreślano nie tylko to, że kanony kultury klas wyższych wpływają na świadomość klas niższych, ale również i to, że uniwersum klas niższych pozbawione jest reguł wzorowanych na regułach klas wyższych, co powoduje liczne ograniczenia w relacjach dotyczących przeszłości między klasami wyższymi a niższymi.

Badania socjologiczne wskazywały na złożoność kultury narodowej oraz kultur lokalnych, na współwystępowanie nowych i starych tendencji, na rolę nomadyczności, przynależności do środowisk i organizacji zarówno w wypadku tworzenia płynnych porządków kulturowych, jak i teatralizacji życia społecznego, a w konsekwencji teatralizacji reprezentacji przeszłego życia społecznego. Zwracano również uwagę na znaczenie materialnych śladów przeszłości oraz na coraz większe znaczenie instytucjonalizacji więzi społecznych, umożliwiających inny typ współbycia z przeszłością (przechodzenie od namysłu intelektualnego do autentyczności przeżycia innej kultury; przeszłość potraktowana w jej przeżywaniu jako obcy kraj). Należy przypomnieć, że coraz większą wagę przykładano do nowych tendencji w formie komunikowania polityk pamięci.

3 B. Szacka, A. Sawisz Czas przeszły i pamięć społeczna. Przemiany świadomości historycznej inteligencji polskiej 1965-1988, Instytut Socjologii, Uniwersytet Warszawski, Warszawa 1988. Badania nad stosunkiem polskiej inteligencji do polskiej przeszłości były prowadzone pod kierownictwem prof. N. Assorodobraj-Kuli głównie przez J. Possart oraz B. Szacką.

4 O tym, czy w czasie PRL-u temat przeszłości jest bezpieczny. czy niebezpieczny, świadczą choćby losy książek Barbary Szackiej na temat pamięci. Przeprowadzone przez nią w latach 6o. badania zostały opublikowane w 1983 r. i sporo było głosów, że "stosunek do przeszłości inteligentów" jest tematem niebezpiecznym. Obecne prace Barbary Szackiej dotyczące postaw Polaków względem historii najnowszej oraz historii II wojny światowej są od razu publikowane. 
W licznych badaniach socjologicznych o zacięciu antropologicznym śledzono też różne formy konkretyzacji, prywatyzacji i lokalizacji pamięci. Coraz częściej przyglądano się wartościom przeszłości związanym z życiem jednostki (chodzi o honor, godność, siłę charakteru). Pokazywano, że wartości ważne i użyteczne z punktu widzenia wymagań legitymizacyjnych współczesnego państwa i narodu „nie pasują" do przeszłych wzorców patriotyzmu heroicznego i militarnego. W ostatnich trzech dekadach, dodajmy, coraz mniej miejsca poświęcano wielkiej historii, a coraz więcej „małej przeszłości”, na przykład rodziny, najbliższego otoczenia. Również w badaniach pojawiły się bardzo istotne politycznie pytania o zmieniające się funkcje pamięci w procesach konstytuowania się pojednania narodowego czy konfliktu. Wreszcie całkiem niedawno podkreślano rolę emocji pozytywnych i negatywnych w budowaniu wspólnoty narodowej lub wspólnoty lokalnej za sprawą zarówno konfliktu, jak i pojednania.

Jak mi się wydaje, w socjologicznych badaniach postaw obywatelskich wobec przeszłości Polski marginalizowano rolę emocji - były one elementem postawy rozumianej wedle postulatów teoretycznych Stefana Nowaka, lecz traktowano je „lekceważąco” lub uznawano za patologiczny komponent postawy społecznej.

Z początkiem XXI wieku nastąpił odwrót od unieważniania kategorii emocji: obecnie następuje maksymalizacja jej ważności (zob. badania na temat pamiętania i zapominania, roli strachów i lęków). Rzec by można, że emocje wyszły $\mathrm{z}$ ukrycia warsztatów badawczych socjologa; z miejsca w uwagach końcowych raportów badawczych przeszły do centralnych ich części. Wyniki zaczęły odsłaniać, jak istotna dla badanych jest problematyka wzniosłości, dumy, odświętności, a także nienawiści, pogardy, lęków i strachów. Badania socjologiczne zwróciły również uwagę na opisy emocjonalnej akcesji jednostek i grup - i to na masową skalę - do wspólnot pamięci lokalnej czy narodowej. Można powiedzieć, że dość dobrze rozpoznały one tworzenie po 1989 roku mocnych uwarunkowań emocjonalnych dla pluralizacji wspólnot realnych i wspólnot będących projektami. Ponadto szybko i wnikliwie reagują na powstawanie tych odniesień do przeszłości, które mogą skutkować nową formą pamięci (rekonstrukcje historyczne). Tak więc wiele badań było zorientowanych na wychwycenie całej złożoności rekonstrukcji historycznych i ich twórców oraz na nowe formy wspólnot kultywujących romantyczno-spiskowe objaśnienia polskich dziejów.

Zauważyć też można, że badania zarówno nad rekonstrukcjami historycznymi, jak i nad katastrofą smoleńską postawiły problem zaufania do przeszłości Polaków w innym świetle. Wyzwoliły chęć instytucjonalizacji 
spontanicznych wspólnot, które miały za zadanie budować wielozmysłową prawdę o przeszłości lub prostymi środkami jedną „prawdę smoleńską”. Warto tu dopowiedzieć, że w badaniach socjologicznych, zwłaszcza z początkiem drugiej dekady naszego stulecia, coraz więcej analiz dotyczyło uwarunkowań, zasad i mechanizmów wytwarzania się wspólnot pamięci narodowej i lokalnej, coraz więcej było i jest odwołań do teorii spiskowych, do tego, co się obecnie nazywa „kulturą konspiracji”, w których pierwszoplanową rolę odgrywają operacje na kulturowych standardach wielkich emocji (na przykład strach przed utratą podmiotowości, strach przed masami).

Po „wycinkach” przygotowanych na podstawie ogólnego oglądu ustaleń socjologicznych dotyczących polskiej przeszłości czas najwyższy na inne „wycinki” socjologiczne i na teoretyzującą socjologiczną diagnozę rzeczywistości polskiej między 1989 a 2016 rokiem. Zanim wskażę najważniejsze elementy, które moim zdaniem uprawomocniają spojrzenie na „pamięć po polsku" z perspektywy podmiotów i strategii organizowania tych pamięci, pragnę na chwilę zatrzymać się na charakterystykach podejścia teoretycznego użytecznego dla tego rodzaju rozważań.

Gdy podejmuje się temat charakterystyk polskiej pamięci, a jakość podejścia teoretycznego i właściwy słownik pojęć nie są przez badacza uważane za mało istotne, przeważa raczej namysł nad sposobami teoretyzowania o strukturach, mechanizmach i funkcjach samej pamięci aniżeli nad ramami teoretycznymi interpretacji właściwości i jej nosicieli: podmiotów indywidualnych i zbiorowych w szerzej lub węziej ujmowanych ich kontekstach społecznych. Taki stan rzeczy zachęca do pytania o sposób teoretyzowania o polskiej rzeczywistości, a co najmniej o to, w jakich kategoriach, w jakiej tradycji teoretycznej ją analizuje my $y^{5}$. Wyborów tradycji i ich uzasadnień może być wiele. (Chodzi mi o tradycje, a nie o jakieś konkretne teorie, raczej o pewną szerszą perspektywę problematyzowania rzeczywistości w kategoriach ogólnych humanistyki). Sadzę, że gdy interesujemy się organizacjami i instytucjami, gdy z badań terenowych wiemy, że nie jest łatwo zarządzać instytucjami, a jeszcze trudniej je przerabiać, tworzyć, to z repertuaru dwóch tradycji: uspołecznienia oraz kompozycji6 warto skupić się na tej drugiej.

5 Por. R. Collins Four sociological traditions, Oxford University Press, Oxford 1994.

6 Korzystam z propozycji porządkowania współczesnych teorii społecznych sformułowanych przez M. Gdulę. Zob. M. Gdula Uspołecznienie i kompozycja, Wydawnictwo Krytyki Politycznej, Warszawa 2015, s. 10 i n. 
Tradycja ko mpozycji wyróżniona, objaśniona i skonkretyzowana przez Macieja Gdulę kładzie nacisk na sposoby wyróżniania aktorów społecznych, na zachodzące między nimi relacje w sytuacjach, które ujawniają różnorodne i radykalne przekształcenia tych relacji. W perspektywie kompozycyjnej, w charakterystycznym dla niej określaniu aktorów, tego, co ich włącza w akceptowany przez nich system społeczny, i tego, co ich z niego wyłącza, istotne jest to, że badacz skupia się nie tyle na wymiarze symbolicznym rzeczywistości, ile na jej materialności. W ramach tego ujęcia uwaga badacza, w tym na przykład badacza pamięci, ukierunkowana jest na organizacje, które nie tylko tworzą wiedzę o przeszłości czy proponują jakąś formę wizualizacji tej przeszłości, lecz także konstruują coś znacznie od wiedzy i żywych obrazów głębszego i szerszego, a mianowicie jakąś formę intensywnego przeżywania, doświadczania przeszłości. Ta perspektywa uwrażliwia też badacza pamięci na formy współdziałania między tymi organizacjami, na to wszystko, co sprawia, że stają się one ważnymi czytelniami dziejów dawniejszych czy nowszych. W obrębie tradycji kompozycyjnej warto więc usytuować roztrząsania na temat wspólnot pamięci lokalnej czy wspólnot pamięci narodowej. Stwarza ona lepsze ramy, narzędzia, by zastanowić się, jak przekształcenia społecznych definicji wspólnoty wpływają na konstrukcje skutecznych organizacji społecznych.

Nie można zapominać, że zajmując się wspólnotami pamięci lokalnej i narodowej, uczestniczymy w rewizji koncepcji wspólnotyw ujęciu normatywnym i jako „partykularnej grupy zintegrowanej przez tradycyjne

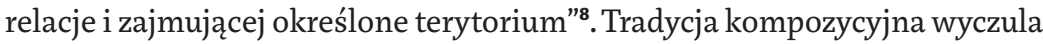
na problemy relacji z innymi grupami, zwraca uwagę na powiązania kooperacji „na zewnątrz" i zdolności zbiorowości do samoorganizacji, zaznacza wagę mobilizacji społecznej, rolę świętowania wielkich wydarzeń, a także kładzie nacisk na to, czy coś jest wymyślone oddolnie, czy narzucone z góry. W tej perspektywie można, w zależności od miejsca w strukturze organizacyjnej, zdobyć „wzmocnienie” teoretyczne dla zainteresowania członkami wyspecjalizowanych organizacji pamięci, intensywnymi związkami uczuciowymi między nimi, ich współdziałaniem w organizacji określonych

7 W tej tradycji chodzi przede wszystkim o przekształcenia relacji w kontekście hierarchicznych struktur społecznych.

8 K. Strzyczkowski Poeci własnych spraw. Wstęp do rozważań o wspólnocie marki, w: Socjologia uspołecznienia. Księga dedykowana Profesor Mirosławie Marody, red. M. Lewicki i in., Wydawnictwo Naukowe Scholar, Warszawa 2015, s. 223. 
form upamiętniania przeszłości, która ma dla nich „walor silnego przeżycia”. Dzięki niej - podkreślmy - łatwiej opisać kolejną fazę zmian zachodzących w Polsce po radykalnej rekonstrukcji demokratyczno-liberalnej lat 8o. Można przygotować swego rodzaju m a pę współdziałania aktorów wewnątrz i na zewnątrz organizacji, której zadaniem jest upamiętnianie przeszłości za pośrednictwem różnych stałych i mocnych form mobilizacji społecznej, na przykład różnego rodzaju wspólnot. Te organizacje i instytucje upamiętniające spełniają różne kryteria: albo wspólnoty bazowej, tradycyjnej, albo wspólnoty wyobrażonej, ideologicznej. Taka mapa jest nie tylko mapą organizacji ujawniającą ich konfiguracje, ale też czymś kategoryzującym przestrzenie między ludźmi i organizacjami. Jest to mapa świata społecznego, w którym spotykają się przestrzenie jednostkowych przeżyć emocjonalnych z innymi, „zimnymi” relacjami między organizacjami służącymi porządkowaniu interpretacji przeszłości dla celów centralnych struktur państwowych. Te sposoby przedstawień relacji i emocji uwzględniają odmienność kryteriów wspólnoty bazowej i wspólnoty ideologicznej; ich skutki dla budowania przeżycia przeszłości wskazują, jak te kryteria generują odmienne sieci współpracy między jednostkami a organizacjami, organizacjami a inicjatywami społecznymi.

Tradycja ko mpozycyjna,jak widać, kieruje uwagę badacza pamięci na współdziałanie, na dostęp do zasobów takich tradycyjnych cech wspólnotowości jak: emocjonalny charakter więzi, etyczność zobowiązań wobec grupy, wyłączność uczestnictwa (wszystkie te właściwości traktować należy jako funkcjonalne konsekwencje współdziałania ludzi i instytucji). Zaznaczyć też trzeba, że ta perspektywa umożliwia nie tylko lepszy ogląd właściwości tradycyjnej wspólnotowości czy zmianę akcentów w odsłanianiu mechanizmu przekształcania wspólnot bazowych we wspólnoty ideologiczne, wyobrażone. Co najważniejsze dla syntetyzujących ujęć pamięci (w skali narodowo-państwowej) oferuje ona wyobrażenie społeczeństwa polskiego ja ko efektu nakładania się "trzech kompozycji społecznych": społeczeństwa wspólnot lokalnych, społeczeństwa wielkich struktur oraz społeczeństwa neoplemiennego (w rozumieniu neoplemion zaproponowanym przez M. Maffesolego ${ }^{9}$ ).

Reasumując, w osadzonej w perspektywie kompozycyjnej diagnozie rzeczywistości Polski instytucje i organizacje pamięci po pierwsze są specyficzne dla społeczeństwa społeczności lokalnych; po drugie współwystępują

9 M. Maffesoli Czas plemion. Koniec indywidualizmu w społeczeństwach ponowoczesnych, Wydawnictwo Naukowe Scholar, Warszawa 2008. 
z instytucjami i organizacjami drugiego społeczeństwa, a mianowicie znajdują się w relacjach z organizacjami kultury mającymi na celu propagowanie wiedzy historycznej na podstawie tej federacji miłośników historii; po trzecie znajdują się w złożonych powiązaniach z instytucjami charakterystycznymi dla społeczeństwa neoplemiennego (na przykład ze spektakularnymi akcjami obywatelskimi, zwłaszcza internetowymi, nastawionymi na obronę jakiejś wizji wydarzeń czy bohatera z przeszłości).

A zatem dla, moim zdaniem niezbędnej, diagnozy ogólnej, dla szczegółowych przedstawień pamięci lokalnej - w ich powiązaniu z różnymi typami wspólnot społecznych - istotne są nie tylko wskazane wyżej ramy teoretyczne (należące do tradycji kompozycyjnej), ale także kategorie pojęciowe związane z określaniem typu czasu społecznego oraz porządków kulturowy ch charakterystycznych dla zmian zachodzących w III Rzeczypospolitej.

Po pierwsze chciałabym podkreślić wagę kategorii różnorodności czasów społecznych, które warunkują odmienne logiki rozwojowe, decydujące o specyfice zmian dokonujących się w Polsce po radykalnej, demokratycznej rekonstrukcji społecznej, politycznej i kulturowej. Czas polskiego społeczeństwa zamyka się w trzech orientacjach intelektualno-emocjonalnych, a mianowiciew orientacji na przeszłość, orientacji na teraźniejszość i orientacji na przyszłość. Tym trzem orientacjom czasowym należy przyporządkować trzy typy kultur określających dynamiczne układy wartości jednostek i grup funkcjonujących albo w for mi e $n$ a w y ku, albo w postaci wy b o r u, ale jako plastyczne pragnienie w odniesieniu do kultury, zwłaszcza do jej aspektu dawności. Dlatego też proponuję ująć diagnozę rzeczywistości polskiej w kategoriach trzech kultur: kultury opartej na tradycji, kultury opartej na projekcie życia indywidualnego, a przede wszystkim życia zbiorowości czy kultury opartej na pragnieniach jednostkowych (ograniczonych jednak charakterem zasobów możliwości konsumpcyjnych).

Po drugie pragnęłabym wskazać, że w tych trzech porządkach wartości kulturowych mamy do czynienia z trzema odmiennymi matry c a mi w s p ól n o t zarówno realnych, jak i wyobrażonych. W ramach pierwszego porządku dominantą jest wzór ws pólnoty tradycyjnej (mierzona stopniami instytucjonalizacji charakterystycznymi dla instytucji naturalnych). W ramach drugiego porządku - wzór w s pólnoty wyobrażon ej (opartej na projekcie aksjologicznie wyrazistym i spójnym). Natomiast w przypadku trzeciego porządku są nią wspólnoty sieciowe czy wspólnoty 
epizodyczne wytwarzane przez różne neoplemiona o bliżej nieokreślonych granicach (w ostatnim przypadku, w odróżnieniu od dwóch poprzednich, to MY organizacyjne jest wielokształtne i płynne).

Dopiero co wskazane podstawowe składniki diagnozy polskiej rzeczywistości zakodowane w kilku kategoriach kulturowych odsłaniają bogactwo i różnorodność strategii przeżywania przez jednostki i grupy zasobów przeszłości - materialnych i niematerialnych, zawartych w dziedzictwie kulturowym. Co dla dalszych analiz najważniejsze, wytwarzają ją aktorzy - jednostki i zbiorowości, na trzech poziomach agregacji polskiej rzeczywistości, a mianowicie na poziomach makro-, mezo- i mikrospołecznym. Ze względu na wagę tych poziomów w analizach socjologicznych w ogóle, w tym i w diagnostyce specyfiki strukturalnej polskiej pamięci, problemy podmiotów je tworzących, występujących jako dominanty na poszczególnych poziomach tej agregacji p o w i n ny, w moim przekonaniu, być szerzej uwzględnione i wnikliwiej potraktowane.

Oczywiście zagadnienie poziomów agregacji społecznej i ich charakterystyk wymaga solidnych dyskusji, i to bardzo różnych, prowadzonych z wielu perspektyw teoretycznych. W tym miejscu analiz chodzi mi tylko o to, by pokazać istotność i konieczność sprowadzenia ogólnego pytania o specyfikę polskiej pamięci w ogóle do pytań o jej specyfikę zadawanych podmiotom z trzech poziomów agregacji społecznej. Sądzę, że jeśli przeprowadzi się ten rodzaj uszczegółowienia, będzie można głębiej wniknąć w uwarunkowania pluralizmu pamięci społecznej, staranniej pytać o białe plamy w badaniach nad pamięcią narodową Polaków, ich pamięcią - regionalną i lokalną oraz tą zrodzoną w niepowtarzalnych mikrosytuacjach życiowych.

Przy odnoszeniu pytań o pamięć, o jej treść i jej nosicieli do poziomów agregacji społecznej istotne okazują się ich hierarchia oraz znaczenia. Innymi słowy, chodzi o określenie, który z tych poziomów jest w określonym momencie historycznym Polski poziomem strategicznym dla orzekania o jakości i specyfice pamięci społecznej „po polsku”. Gdy w taki mniej ogólny sposób pytamy o pamięć, o pamięć związaną z poziomami agregacji, inny sens zyskuje na przykład pytanie o genezę pamięci: można dzięki temu pytać, na którym z tych poziomów agregacji zmiany pamięci zbiorowej się zaczynają, gdzie uzyskują wzmocnienie, a na którym z nich następuje tej pamięci kulturowe zwieńczenie, itd.

Właśnie te pytania o strategiczną dla badań nad pamięcią „,zęść polskiej rzeczywistości" ujmowanej przestrzennie pozwalają moim zdaniem lepiej dostrzec wagę poziomu mezo i znajdujących się na nim zorganizowanych 
zbiorowości, instytucji, a także wytwarzanych solidnych projektów czy tylko ulotnych pragnień. Dzięki temu można, zachowując tezę o trójpodziale kulturowym Polski, pytać o to, gdzie trzeba szukać specyficznych instytucji, którymi są zorganizowane wspólnoty pamięci i życia. Można też ustalać, jakie to ma znaczenie wtedy, gdy socjologowie są zapatrzeni w systemy organizacji pamięci na poziomie makrospołecznym, na którym znajduje się większość sformalizowanych struktur syntetyzujących masowe, mające charakter globalny procesy emancypacyjne, środki modernizacji całych narodów, państw czy przeciwnie - usytuowane są wielkie masowe procesy retradycjonalizacji. Ważne jest to również i z innego zupełnie powodu, mikrospołecznego poziomu elephantiasis, w wyobraźni badaczy i samych badanych. Kultura indywidualizmu właściwa drugiemu porządkowi kultury dostarcza podmiotom środków nobilitacji różnych pragnień i emocjonalnych oczekiwań.

Dowartościowanie drugiego poziomu agregacji społecznej w pamięci, rzec można, pomostowej między sferą wielkich narracji, totalnych projektów, masowych ideologii, religii a sferą małych historii jednostkowych, rodzinnych, środowiskowych jest zabiegiem interpretacyjnym o istotnych konsekwencjach. Jest to poziom, który wymaga wielkiej uważności ze strony badaczy, albowiem to na nim tworzą i rozpowszechniają swoje wizje wspólnot masowi uczestnicy inicjatyw obywatelskich, lokalnych i krajowych; to tutaj aktywiści społeczni działają na co dzień, a nie od święta, podczas wyborów do sejmu itd. czy podczas obchodów świąt scalających społeczeństwo. (Mamy z tego poziomu nadmiar danych empirycznych zarówno tych przygotowanych przez akademików, jak i tych pozyskiwanych przez „aktywnych obywateli”. Podmioty te nieustannie przetwarzają swoje doświadczenia życiowe i sprawiają, że stają się one podwalinami klubów i stowarzyszeń wysoce waloryzujących przeszłość).

Z zasygnalizowanych powyżej powodów (można ich wskazać oczywiście znacznie więcej) proponuję, by w pracach nad ustalaniem specyfiki polskiej pamięci, jeśli nie koncentrować się na poziomie Polski lokalnej, tym środkowym poziomie, i przyglądać się na nim konfiguracjom instytucji i reprezentowanym przez nie wartościom, to warto więcej uwagi poświęcić kulturze wspólnotowej w ogóle, w tym zwłaszcza wspólnotowym kulturom pamięci występującym na środkowym poziomie agregacji społecznej.

$\mathrm{Na}$ podstawie po pierwsze prac na temat wielokulturowości polskiej, po drugie badań na temat enklawowego charakteru społeczeństwa obywatelskiego w Polsce, po trzecie danych o coraz większej dekonstrukcji struktur państwowych dotyczących poziomu mezo można powiedzieć, że ulokowane 
na nim jednostki, środowiska, organizacje stale uczestniczą w tworzeniu, propagowaniu, a także kontrolowaniu wspólnot realnych i wyobrażonych, opartych na różnych sposobach przeżywania związków z przeszłością społeczeństwa polskiego.

Trzy wskazane wcześniej porządlki kulturowe na poziomie mezo są przedstawiane za pośrednictwem różnych typów wspólnot odnoszących się do przeszłości zarówno określonych społeczności lokalnych, jak i całego społeczeństwa narodowego. To tu właśnie ulokowane są wspólnoty o różnych stopniach instytucjonalizacji struktur zasobów tożsamościowych budujących MY.Z wielu różnych powodów, w tym na pewno z powodu czysto akademickiego, uważam, że na tym poziomie dzieje się wiele ważnego nie tylko dla teorii społecznej, ale i dla Polski, dla obywateli zaangażowanych w jej doskonalenie. Jest to istotne przede wszystkim dla określania specyfiki polskiej pamięci. Tutaj usytuowane są wspólnoty pamięci narodowej i lokalnej, od których zależy zarówno rewolucja, jak i kontrrewolucja społeczna i kulturowa, zazwyczaj ideologicznie konstatowane na poziomie makrospołecznym. Również tu umieszczane są instytucje i organizacje regulujące, od których zależy jakość naszego życia indywidualnego lub naszych skrytych pragnień.

Chodzi mi w tym wszystkim o podkreślenie, że w diagnozach syntetyzujących dane i interpretacje na temat różnych wspólnot (tradycyjnych, projektujących czy sieciowych) z tego poziomu istotne jest wskazanie argumentów teoretycznych i empirycznych przemawiających za tym, że wspólnoty pamięci z poziomu mezo są znaczące w socjologicznym określaniu wspólnot istotnych dla polskiej pamięci. Sądzić można, że wspólnoty te - w większości (chodzi mi nie tylko o ich masową publiczną widoczność) do niedawna stanowiące to, co Anthony Giddens nazywał „zapleczem” czy „wnętrzem” frontu makroideologii, składały się z pamięci lokalnej, w tym i lokalnych wersji pamięci narodowej - obecnie „ujawniły się” na wszystkich trzech poziomach agregacji społecznej. Odwołania do nich można znaleźć wszędzie, począwszy od wielkich manifestów politycznych wygłaszanych w sejmie, a skończywszy na polityce historycznej uprawianej przez rodziny przy okazji świąt. To właśnie na poziomie mezo, w tym miejscu zróżnicowanej rzeczywistości kulturowej Polski powstały i funkcjonują archipelagi organizacyjne polskości i lokalności w języku potocznym ${ }^{10}$. Tym instytucjonalnym nośnikom przydano nazwę

10 Za: A. Zybertowicz, http://rebelya.pl/post/210/informacja-komunikacja-przywodztwo-klucze-do-zm (17.01.2017). 
„archipelagi polskości”"11; chciałabym dodać także „archipelagi lokalności”, w mniejszym lub większym stopniu „podszyte" narodem, państwem.

Nie trzeba chyba przypominać, że tworzenie na tym poziomie wielokształtnego ruchu społecznego i politycznego doprowadziło do zmiany prezydenta, rządu, parlamentu, stworzyło podstawy społeczne i kulturowe rewolucji społecznej, która przybrała kostium jednocześnie narodowy i lokalny. Wydaje się zatem, że problematyka wspólnot pamięci ze środkowego poziomu, szczególnie dotycząca ich typologii i funkcji integracyjnych, i to taka, dla której ważne są zarówno wartości poznawcze, jak i emocje (nie tylko te skrajne), jest dobrym wprowadzeniem do klasycznych dla różnych socjologii ujęć wspólnot, do centrum refleksji nad sposobami budowania przez społeczeństwo i jego segmenty specyfiki polskiej pamięci.

Sądzę, że sedno polskiej pamięci tkwi we wspólnotach pamięci narodowej i wspólnotach pamięci lokalnej. Miał rację Marian Kempny ${ }^{12}$, gdy pisał o bogactwie form uspołecznienia w Polsce, które przekracza wyobraźnię klasyków socjologii. Kierując się jego przekonaniem, odnoszącym się także do wielości form wspólnotowych, należy rozstać się z popularną opinią, że wspólnoty pamięci narodowej i wspólnoty pamięci lokalnej ulokowanej na poziomie mezo realizują jedynie wzorce tradycyjne, związane z genealogią i funkcjonowaniem instytucji naturalnych, czyli rodzin i małych środowisk. Liczne i wartościowe badanie różnego typu stowarzyszeń, klubów, instytucji i organizacji wyspecjalizowanych w kultywowaniu wiedzy i emocji związanych z przeszłością udowadniają, że wspólnoty te nie są jedynie egzemplifikacją starych wspólnot wiejskich, „ulubionych form klasyków socjologii”, ale również przykładami „nowych wspólnot” - wspólnot ochronnych, „nowoplemion" czy wspólnot wirtualnych, czyli wyobrażonych wspólnot pozostających poza obrębem tradycyjnych socjologicznych typologii.

Gdy wiedzę o drugim poziomie agregacji społecznej i charakterystycznych dla niego instytucjach dostarcza socjologia organizacji, okazuje się, że socjologowie ciekawi są zwłaszcza wspólnot zorganizowanych, które nie spełniają trzech podstawowych warunków stawianych tradycyjnym wspólnotom. Ma

11 P. Krygiel "The Archipelago of Polishness in the perspective of the sociology of social movements. An attempt at description and interpretation", założenia pracy doktorskiej, niepublikowany maszynopis, por. M. Łuczewski Naród jako ruch społeczny, "Studia Socjologiczne” $2011 \mathrm{nr}$ 3, s. 202.

M. Kempny Socjologia ponowoczesnych form społecznych: wspólnoty i kultury „bez korzeni”, czyli o tym, jak próbuje się uchwycić naturę relacji społecznych w świecie ruchu i mieszania się, "Kultura i Społeczeństwo" 2006 t. 50 nr 1-2, s. 13-39. 
rację Marek Ziółkowski ${ }^{13}$, zauważając, że podział grup wspólnotowych ze względu na trzy podstawowe cechy: aspekt obiektywny - podobieństwo cech interesów, aspekt subiektywny - poczucie więzi oraz aspekt zachowaniowy - realna współpraca, nie pozwala na ich sensowne podzielenie. Dołączam się do tej opinii i sądzę, że to, „co się dzieje” na drugim poziomie społecznej agregacji Polski, pozwala wypracować badaczom nowy system kategoryzacji wspólnot pamięci, system oparty przede wszystkim na rodzaju interakcji i komunikacji, a zależny także od „klimatu”, jaki w danej zbiorowości panuje.

Posiłkując się kategoryzacją M. Dmochowskiej ${ }^{14}$, uważam, że wspólnoty pamięci lokalnej oraz wspólnoty ${ }^{15}$ pamięci narodowej, występujące w różnych kostiumach organizacyjnych, dają się podzielić na: wspólnoty miejsca, wspólnoty członkowskie, sieci przyjaźni skupione w jednym miejscu, rozproszone sieci przyjaciół, wspólnoty oparte na członkostwie skoncentrowanym na jakiejś wspólnej aktywności, wspólnoty członkowskie oparte na wierze, wspólnoty wyobrażeniowe, ale bez konieczności kontaktów face to face, czy wreszcie wspólnoty wirtualne ${ }^{16}$. Na poziomie mezo da się także wyróżnić wspólnoty typu ochronnego, to jest te, które na przykład chronią jakąś mniejszość społeczną czy narodową przed utratą pamięci o przodkach. Przyglądanie się różnym stowarzyszeniom, które miały i mają w swych statutach „spotkanie z polską przeszłością”, to nic innego jak lepsze lub gorsze odsłanianie wzorów odchyleń od matrycy tradycyjnej wspólnoty. To, jak sądzę, generuje sytuacje, w których możliwe jest dopatrzenie się w konkretnej organizacji znamion nowych wspólnot i ich bardziej subtelnych kategoryzacji.

Wydaje się, że wiele konkretnych wspólnot pamięci lokalnej i wspólnot pamięci narodowej spełnia kryteria now y ch w s pól not. Warto zwrócić uwagę na co najmniej trzy z nich. Po pierwsze ze względu na wspólną tradycję organizacje i stowarzyszenia mogą przybierać formy (kolejno od

13 M.Ziółkowski Teoria socjologiczna a transformacja społeczeństwa polskiego, Wydawnictwo Naukowe Scholar, Warszawa 2015, zwłaszcza cz. 2.

14 M. Dmochowska Wspólnoty - fundamenty czy fasady polskiej struktury?, w: Kulturowe aspekty struktury społecznej. Fundamenty, konstrukcje, fasady, red. P. Gliński, I. Sadowski, A. Zawistowska, Wydawnictwo IFiS PAN, Warszawa 2010.

Za: tamże.

Wszystkie te rodzaje wspólnot daje się wykryć w terenie. Realizują je kluby sportowe, stowarzyszenia miłośników historii poszczególnych ziem, fundacje rodzinne czy kluby "Gazety Polskiej", por. M. Ślarzyński Spotkania kultury lokalnej z kulturq̨ narodową w działaniach Klubów "Gazety Polskiej", "Górnośląskie Studia Socjologiczne. Seria Nowa” 2015 nr 6, s. 175-193. 
najmocniejszej wspólnej tradycji do najsłabszej) albo wspólnot tradycyjnych, albo wspólnot ochronnych, albo nowoplemion, albo wspólnot wirtualnych. Po drugie, gdy weźmiemy pod uwagę świadomość MY, to istniejące wspólnoty tradycyjne i nowe (zakładamy, że tworzą one kontinuum) możemy podzielić na ochronne, tradycyjne wyobrażone (wirtualne) i nowoplemiona (tu mamy z kolei do czynienia z gradacją od najsilniejszej świadomości MY do najsłabszej). Po trzecie istniejące konkretne postaci organizacji i instytucji dają się też dzielić ze względu na wymiar temporalny: zgodnie z nim możemy wyróżnić wspólnoty ochronne, nowoplemiona, wspólnoty tradycyjne i wspólnoty wyobrażone, wirtualne (uporządkowanie od najbardziej konkretnej orientacji czasowej do bezczasowości).

Staranne przedstawianie sta rych i n ow y ch form wspólnot pamięci lokalnej i narodowej to wedle wskazanych wymiarów zadanie na długie lata dla wielu zespołów badawczych. Trzeba je gromadzić, porządkować i systematyzować. Teraz pragnę tylko zwrócić uwagę, że te wspólnoty coraz bardziej zarządzają poczuciem wspólnej tożsamości. Wydaje mi się, że można mówić o ostatnich dwóch dekadach w Polsce jako o okresie „głodu przynależności” do czegoś, co jest „swoje” i „nasze”, z czym można się identyfikować i co jest wybrane oraz dobrowolne. Chodzi mi o to, by badacze pamięci chętniej niż dotąd przyglądali się stowarzyszeniom i środowiskom kultywującym pamięć, by zwracali uwagę na nowy głód przynależności do wspólnot pamięci, na poszukiwanie obrazu przeszłości Polski w świecie gier. Pragnę podkreślić, że to nie tylko stary, tradycyjny głód przynależności do określonej wspólnoty pamięci nadal trwa i obowiązuje, ale że zyskują na znaczeniu coraz liczniejsze wspólnoty pamięci narodowej i wspólnoty pamięci lokalnej. Jak pokazują przykłady, powstawanie, mnożenie się stowarzyszeń o charakterze wspólnot wirtualnych ujawnia syndrom nowego głodu, głodu nowych przynależności wspólnotowych.

Badania społeczności lokalnych w Polsce ${ }^{17}$ pozwalają mi sądzić, że właśnie wspólnoty pamięci lokalnej i pamięci narodowej w pełni ujawniają ponowoczesne wartości i stanowią kontinuum: od wspólnot tradycyjnych, przez

17 J. Kurczewska Lokale Gemeinschaften und Kollektives Gedächtnis, w: Erinnerung auf Polnisch Texte zu Theorie und Praxis des sozialen Gedächtnisses, Hgrs. R. Traba, P.O. Loew, Deutsch-Polnische Erinnerungsorte Band 5, Ferdinand Schöningh Verlag, Paderborn 2015, s. 121-142. K. Malicki Polacy i ich pamięć przeszłości. Studium socjologiczne pamięci zbiorowej na przykładzie regionu podkarpackiego, Wydawnictwo Nomos, Kraków 2012; zob. także: Stan i zróżnicowanie kultury wsi i małych miast, red. I. Bukraba-Rylska, W. Burszta, Narodowe Centrum Kultury, Warszawa 2011. 
grupy pierwotne, wspólnoty ochronne ${ }^{18}$ czy - wedle Maffesolego ${ }^{19}$ - nowoplemiona, aż po szczególny rodzaj wspólnot wyobrażonych, czyli wirtualnych (opisywanych z kolei przez Castelsa ${ }^{20}$ ).

W pewnego rodzaju podsumowaniu można chyba powiedzieć, że wśród wspólnot lokalnych i narodowych, składających się odpowiednio na „archipelagi polskości lub/i archipelagi lokalności", mamy do czynienia nie z opozycją wspólnoty tradycyjne $v s$ wspólnoty nowe, lecz z procesem przekształceń jednych wspólnot w drugie. Innymi słowy, o strategicznej roli wspólnot pamięci narodowej oraz pamięci lokalnej z mezo poziomu wśród wspólnot narodowych i wspólnot lokalnych występujących na wszystkich trzech poziomach agregacji społecznej świadczy to, że właśnie one mają tendencję do płynnego przechodzenia od stanu dychotomii: tradycyjne vs wirtualne do stanu kontinuum, co sprawia, że rzeczywistość polska jest dynamiczna i innowacyjna. Jest tak, ponieważ poziom drugi jest tym poziomem, który zarówno pełni funkcje kontrolne w trakcie gromadzenia zasobów pamięci, jak i gra rolę podstawowego przekaźnika zasobów między poziomami makro- a mikrospołecznym.

Pragnę zauważyć, że współczesna Polska stanowi żyzne podłoże dla nowych rodzajów wspólnot pamięci narodowej i lokalnej. Wydaje się, że kodowane przez te wspólnoty bogactwo różnych narracji historii narodowych daje Polakom impuls do ustawicznego wytwarzania wspólnot, do ich przetwarzania, co jest istotne zwłaszcza w okresie zmian ustrojowych. Tym różnym wspólnotom poświęcone są działania licznych stowarzyszeń, klubów wysoce wyspecjalizowanych w kultywowaniu historii. Dzieje się to zresztą za pośrednictwem rozmaitych środków organizacyjnych. Trzeba zaznaczyć, że zarówno treści przekazów tych organizacji o przeszłości, jaki i sposoby działania organizacji magazynują - za sprawą różnych form kultury - rep re zentacje nie tylko emocji pozytywnych, ale i negatywnych. Te emocje, ich splot będący ilustracją jakiejś ważnej normy, chęć zachowania nadal w pamięci jakiegoś dawniej wytworzonego przeżycia radości i dumy czy przeciwnie - poczucia niesprawiedliwości dziejowej, przypomnienia jakiegoś doznanego w przeszłości poniżenia przez własną grupę, rodzinę lub przyjaciół, stanowią „jakąś część” (ciekawym problemem empirycznym jest

18 B. Wellman Virtual communities as communities: Net surfers don't ride alone, w: Communities in Cyberspace, eds. M.A. Smith,P. Kollock, Routledge, New York 1999, s. 167-196.

M. Maffesoli Czas plemion... 
ustalenie przez badacza konkretnego czasu, konkretnej przestrzeni społecznej) konstytucji, wspólnoty pamięci jako wspólnoty także emocjonalnej.

Wspólnoty pamięci coraz częściej są interpretowane w kategoriach wspólnot emocjonalnych (do tego służą liczne badania z zakresu socjologii i antropologii emocji); mają bardzo zróżnicowane formy artykulacji: są fundacjami rodzinnymi upamiętniającymi jakichś wybitnych przodków, stowarzyszeniami miłośników jakiejś ziemi, klubami kombatantów; są, jeśli da się to wykryć w materii pamięciowej, magazynami różnych komponentów odnoszących się do określonej terytorialnie czy tylko symbolicznie pamięci, zawierających w sobie jakieś „zaczepy” dokumentacji stanów emocjonalnych, które można „od nowa przeżywać”. Porównanie zorganizowanych wspólnot pamięci do magazynów to nie tylko popularna metafora, funkcjonująca w życiu współczesnego konsumenta, ale przede wszystkim odwołanie do koncepcji A.i J. Assmannów pamięci zmagazynowanej (magazynującej) czy mniej bezpośrednio - do P. Sloterdijka koncepcji „banków gniewu”21.

Przypomnijmy tę ostatnią koncepcję, mniej znaną badaczom pamięci niż koncepcja Assmannów. Tak oto Sloterdijk objaśnia zasadę i sposoby funkcjonowania „banków gniewu” we współczesności: ich funkcjonowanie to

przejęcie lokalnych zasobów złości i rozsianych projektów nienawiści przez pewną instancję o szerszym zasięgu, której zadanie, jak w każdym autentycznym banku, polega na pełnieniu roli punktu zbiorczego i agencji realizacji. Przejście to wpływa nieuchronnie na strukturę temporalną uwikłanych w pojedyncze projekty potencjałów. Tak jak zemsta jako gniew w formie projektu rozciąga go w czasie i pozwala dojrzewać pragmatycznemu planowaniu, tak gniew w formie banku wymaga od pojedynczych mścicielskich impulsów włączenia się w pewną nadrzędną perspektywę. ${ }^{22}$

W mojej diagnozie polskiej pamięci przedstawionej z perspektywy konfiguracji w przestrzeni społecznej komponentów pamięciowych (wytwarzanych przez organizacje lokalne i regionalne) chodzi przede wszystkim

P. Sloterdijk Gniew i czas. Esej polityczno-psychologiczny, Wydawnictwo Naukowe Scholar, Warszawa 2011.

Tamże, s. 73. Cytat ten, pokazuje nie tylko to, co określa podstawową zasadę swoistej gospodarki gniewu we współczesnym, kapitalistycznym społeczeństwie, ale i sposoby gromadzenia tego gniewu (zob. nasycone emocjami porównanie do banku). 
o tworzenie narodowej pamięci na podstawie ustawicznego budowania przez różnorakie organizacje i aktorów indywidualnych magazynów pamięci lokalnej i regionalnej.

Gdy interesujemy się pamięcią, wspólnotą, polityką i aktorami społecznymi, warto zapytać, czy zakładając organizacje na rzecz ochrony pamięci lokalnej i narodowej, jesteśmy „tu i teraz” w Polsce skazani na zarządzanie gniewem. Można sądzić, że tak. Wskazuje na to stan Europy, w której „w obecnych czasach wszyscy czynią się po trosze członkami mniejszości, po trosze wygnańcami"23, w której jednostki i zbiorowości nie potrafią ani uniknąć, ani wybrnąć z sytuacji, w których gromadzą się zawiść i upokorzenia, gdy u słabszych aktorów zmiany społecznej pojawia się gniew na tych, którzy są jej beneficjentami, którzy wygrali walkę o uznanie dla swojej interpretacji historii, zwłaszcza tej nie tak dawnej.

Świat lokalny Polski początku XXI wieku nie jest, i to trzeba cały czas podkreślać, światem wspólnot terytorialnych, w których oczekiwania i pożądania są w pełni regulowane przez uspójnione tradycje. Jest to świat współistnienia lub rywalizacji dawnych i nowych wspólnot pamięci, świat, w którym pragnienia utrwalenia swoich interpretacji przeszłości nie mogą zostać w pełni i u wszystkich zrealizowane. W ten świat Polski lokalnej interweniują rozmaite media, i te dawne, i te najnowszej generacji, one też uczestniczą w interpretowaniu przeszłości w języku niesprawiedliwości albo poczucia, że przychodzi czas, by wyrównać stare rachunki, nie czekając na pomoc Boga, losu czy polityki. Gniew może zdominować wspólnoty pamięci zorganizowane przez słabych aktorów, uruchamia emocje (na przykład za pośrednictwem radia, szeptanych opowieści) i tym samym stwarza w tych słabych aktorach poczucie, że zagrożone są wspólnoty pamięci, szczególnie te nowe, tworzące się w Polsce lokalnej. Ułatwia odsłonę, w jakim miejscu społecznym brakuje alternatyw organizacyjnych, pokazuje deficyty wspólnot pamięci opartych na emocjach innych niż te wynikające z niespełnionych oczekiwań. Jeśli nie ma tego rodzaju agory (może też wspólnot mniej sformalizowanych, lecz dopuszczanych do głosu w przestrzeni publicznej, by dać świadectwo swojej wizji historii), wentyli bezpieczeństwa nie tylko politycznego, lecz kulturowego, następuje wtedy na poziomie organizacji kumulacja gniewu z wnętrza wspólnot pamięci, a w konsekwencji i z innych fragmentarycznych czy całościowych wspólnot operujących w innych miejscach przestrzeni społecznej. Gniew na tych, którzy nie chcą przystać na naszą wizję historii Polski, jej 
bohaterów i antybohaterów, żywi się toposem romantycznym, wizją katastrofy smoleńskiej, ich banalizacjami. Gniew skierowany przez aktorów na wszystko to, co na zewnątrz naszej wspólnoty, może intensyfikować poczucie bycia razem i bardziej konsolidować wspólnotę w historii "tu i teraz" niż letnie uczucia albo zadowolenie z siebie lub małej czy dużej ojczyzny.

Dość popularna jest opinia, że wspólnoty skonsolidowane na podstawie gniewu (znaleźć je można wśród tych, które stanowią oparcie instytucjonalne dla „pamięci po polsku”) są stabilniejsze niż wspólnoty bazujące na emocjach pozytywnych, bardziej oporne na ograniczenia, bardziej mobilizujące do działań negatywnych. Seanse nienawiści do wrogów danej interpretacji historii bardziej integrują niż te, które odwołują się do inkluzji i bezwarunkowej agape. Nie wolno więc zapominać, że w odniesieniu do przeszłości łatwiej dzielić się gniewem niż emocjonalnymi przeciwieństwami.

Sądzę, że zwrócenie uwagi na myślenie Sloterdijka o bankach gniewu jako o istotnym elemencie podstawowych charakterystyk współczesności ma pewne zastosowanie w proponowanej przeze mnie diagnozie lokalnych i regionalnych fundamentów pamięci polskiej. Nie chce twierdzić, że współczesna pamięć lokalna Polaków nie jest niczym innym niż tylko magazynem gniewu czy wstydu. Innymi słowy, nie jest moim celem, by horyzont emocji negatywnych przesłonił złożoność emocjonalną wspólnot pamięci aktorów i instytucji lokalnych i regionalnych. A zatem nie chciałabym koncentrować diagnozy na redukcji emocjonalnych elementów wyłącznie do ich skrajnych postaci, do ich negatywnych form. Uważam tylko, że w myśleniu o „bankach gniewu", zaproponowanym przez tego holenderskiego filozofa, ważne są miejsce i moment sytuowania emocji wyzwalających jakiś proces przeżywania zbiorowego. Innymi słowy, jego interpretacje zwracają uwagę na formy przeżywania zbiorowego, na momenty i sytuacje uruchamiania perspektywy jako pewnej nadrzędnej interpretacji. Właściwości wspólnot tradycyjnych czy wyobrażonych w różnych połączeniach ich atrybutów ma wspólnota lokalna, a w większym jeszcze stopniu, i tak się chyba dzieje w przypadku Polski, wspólnota narodowa o - rzec by można - wampirycznym, emocjonalnym charakterze. Podkreślana przez Sloterdijka nadrzędna perspektywa zachęca badacza pamięci społecznej do większej wrażliwości na zorganizowane masowe nośniki różnych form pamięci lokalnej i regionalnej.

Koncepcja Sloterdijka oraz koncepcja Antoniny Kłoskowskiej24 „centrów kultury narodowej" na poziomie lokalnym i regionalnym pozwalają postawić 
jedne z ważniejszych pytań o genezę i główne mechanizmy nieustannego budowania wspólnot pamięci na podstawie zróżnicowanych, jak się zdaje, nie tylko negatywnych komponentów emocjonalnych. W przypadku koncepcji Kłoskowskiej25 określenie „centrum” może być używane w stosunku do konkretnych klubów, stowarzyszeń itd., pozwala ogniskować uwagę badacza na tym wszystkim, co sprzyja uogólnianiu sensów nagromadzonych danych, które dotyczą przeszłości lokalnej czy regionalnej i w różnych konfiguracjach składają się na względnie skodyfikowane wyobrażenia przeszłości i przeszłości narodowej Polaków. Innymi słowy, terminy „bank” i „centrum” podkreślają, że rozważany nośnik (w tym przypadku pamięci) jest czymś zorganizowanym, jakoś uporządkowanym, uznanym za wartościowy i użyteczny.

Można powiedzieć, że te konkretne magazyny pamięci lokal nej i regionalnej (określenia te należy wiązać z dopiero co wskazanymi koncepcjami banków i centrów) nabierają dodatkowych znaczeń za sprawą asocjacji z koncepcjami Sloterdijka i Kłoskowskiej. Wiążą się one z koncepcją zwrotu ku emocjom i ku praktyce (zwrot performatywny). Chodzi o to, że znajdujący się w tych magazynach pakiet pozytywnych emocji związanych z dziejami miasta czy z biografią wybitnego obywatela jakichś ziem trafia pod jakieś centralne kierownictwo, na przykład nadrzędną perspektywę, która porządkuje zebrane dane pamięci różnych osób i zbiorowości składających się na funkcjonowanie pewnego magazynu pamięci. Wtedy to traci możliwość indywidualnych realizacji określonych uczuć z powodu działań coraz bardziej wspólnych działań na rzecz jakichś wizji przeszłości i zawartych w niej wartości jako powodów do nostalgii czy - przeciwnie - do radykalnego jej odrzucenia.

Z tego właśnie powodu istotne staje się pytanie, kto z „pracowników” owego banku jest zarządcą jakiejś formy emocji; można powiedzieć, że te mechanizmy wytwarzają sytuacje, w których pojedyncze, lokalne wybuchy dumy czy złości na przodków lub na to, co oni nam uczynili, stają się źle widziane przede wszystkim z powodu ich bezcelowości. Owe magazyny nieustannie wytwarzają „kierowników”, którzy są bardziej od innych kierowników wyspecjalizowani w zarządzaniu różnymi formami wyrazistych, jednoznacznych emocji pozytywnych i negatywnych, odnoszących się do połączonych

25 Tamże. O centrum opolskości A. Kłoskowska mówiła na seminariach związanych z programami badawczymi identyfikacji narodowych. W książce Kultury narodowe... sformułowała koncepcję centrum kultury narodowej (zwłaszcza rozdz. V i Vl, s. 299-414) w odniesieniu do wybitnych jednostek oraz grup pokoleniowych. 
realizacji jakichś określonych zadań wspólnoty. Z tego powodu wydaje się, że istnieją w obrębie tych organizacji magazynujących pamięć lokalną i regionalną ci, którzy nie tylko umieją podporządkować i ukierunkować jakieś działania na rzecz pamiętania określonej dawności, ale i potrafią zbudować sens tych wyobrażeń dawności lokalnej, które składają się na nadrzędną perspektywę ogólnonarodową. Innymi słowy, zarządzanie emocjami „przez centralne kierownictwo" owych organizacji spełniających wyłącznie funkcję nośnika pamięci lokalnej albo funkcję jednego z wielu nośników lokalnej pamięci narodowej winno być przedstawiane i starannie interpretowane, aby odkryć zawarty w nich, nieustannie rozwijający się program interpretacji przeszłości.

Przykładów działań takich lokalnych wspólnot pamięci jako magazynów czy banków ${ }^{26}$ - centrów dumy lub upokorzenia i gniewu - można w Polsce bez trudu wiele wyliczyć. Nie zawsze ich działania są dobrze dokumentowane przez właściwych im „kronikarzy”; często kronikarze działań tych stowarzyszeń, klubów, fundacji unieważniają czy lekceważą wyzwolone przez poczucie dumy albo gniewu i upokorzenia emocje, które w opinii tych, którzy składają się na te stowarzyszenia, kluby i fundacje powinny być wyrażane. Jednym z zadań badaczy jest odkrywanie zasobów emocji, które stoją za zupełnie nieadekwatnymi określeniami, jak historia miejscowości czy sukcesy rodziny; bardzo często pod tymi nazwami ukryty jest wielogłos głębokiego, wielopokoleniowego upokorzenia lub poczucia niesprawiedliwości przekazywanego z pokolenia na pokolenie (często ugrzecznione opisy przeszłości lokalnej i regionalnej nie wskazuja, że następcy sformułują w imieniu swoich przodków jakieś prawo do zemsty albo okażą sprawiedliwy gniew za krzywdy poniesione w dalekiej przeszłości).

Właśnie zakrywanie, unieważniane czy tylko lekceważenie emocji przez kronikarzy zachęcają jednostki i małe grupy funkcjonujące w przestrzeni danej organizacji do wyrażania swoich przekonań na temat dawności w sposób nieobjęty na przykład zasadą poprawności politycznej.Zwrócenie uwagi na miejsce i rolę zarządców emocji, i to nie tylko przez kronikarzy, pozwala znacznie pełniej interpretować przeszłość, nie pozbawiać jej odczytania emocjonalnego, które prowadzić może nie tylko do apologii, ale i wręcz

26 Kluby "Gazety Polskiej”" znajdujące się w większości większych i średnich miast Polski prowadzą ożywioną działalność kronikarską, nie wchodzę tu w ocenę ani tej działalności, ani jakości formułowanych w jej ramach przekazów kulturowych; zob. M. Ślarzyński Spotkania kultury lokalnej..., s. 175-193. 
przeciwnie - do wyrażania różnych form krytyki, a nawet zachęcania do rozstań z jakąś wizją przeszłości.

Warto dostrzec, że organizacje lokalne i regionalne pełniące funkcje zarówno wspólnotowe, jak i magazynujące pamięć, nieodrzucające przy tym komponentu emocjonalnego - tak zwykło się dziać w większości małych i średnich miast lokalnej Polski - ujawniają schematy przeżywania odczytane jakże trafnie przez holenderskiego filozofa. Stworzone przez Sloterdijka koncepcje „banków gniewu” pozwalają dostrzec siłę tych, którym nie powiodła się rywalizacja w warunkach nowego ładu społecznego i gospodarczego. Ci niezadowoleni, których znaleźć można w rozważanych przez nas organizacjach, nie tylko krytykują swoje otoczenie lokalne, swój establishment regionalny, ale robią coś więcej - przenoszą swoje niechęci do tego, co lokalne, na to, co ogólnonarodowe, i jednocześnie stają się zasobem dla tworzenia polityki historycznej przez organizacje i instytucje na poziomie ogólnonarodowym i ogólnopaństwowym. Można powiedzieć, że zarówno na poziomie lokalnym, jak i ogólnonarodowym tworzą się mocne powiązania tych organizacji ze środowiskami działającymi na skalę ogólnokrajową, jak na przykład lokalne środowiska pseudokibiców wyrażają swój zachwyt nad powstaniem warszawskim i czynią zeń centralne wydarzenie heroiczne. Wskazane mechanizmy i zasoby z poziomu mezo, czyli lokalnego, stają się na swój sposób oczywiste na poziomie magazynowania pamięci przez jednostki i środowiska na poziomie ogólnokrajowym.

Wskazane wyżej sposoby tworzenia i podtrzymywania wyrazistych wspólnot emocjonalnych na poziomie mezo agregacji społecznej bez wątpienia pokazują, jak ważne jest powiązanie organizacji wspólnot z manifestowaniem przez ich członków swoich tożsamości społecznych. Liczne badania, zwłaszcza te jakościowe (tym szczególnie blisko do metodologii etnografii czy antropologii), dowodzą, że poczucie bliskości, swobodne manifestowanie uczuć, pasji, własnej tożsamości jest wyjątkową wartością „teraz”. Jest tak zwłaszcza wtedy, gdy dotyczy to inkorporacji przeszłości w konstruowane „tu i teraz" doświadczenie siebie i świata społecznego. Badania te ujawniały, że wyrażanie własnej tożsamości przez odniesienia do przeszłości mają stale wyjątkową wartość, co może być efektem ustawicznego przeżywania utraty nie tylko przez wiele jednostek, ale także przez tysiące środowisk i organizacji. Wspólne, zorganizowane przeżywanie raczej klęsk niż sukcesów czyniło z przeszłości jeszcze cenniejszą wartość duchową.

Różnorodność zastanych, starych wspólnot pamięci lokalnej oraz wspólnot pamięci narodowej, z pozoru funkcjonujących na podobnych zasadach jak 
w XIX wieku, a także ich zdolność do przekształcania się w nowe typy wspólnot, które reagują za pomocą nowych technologii komunikacyjnych na dane zebrane w bliższej lub dalszej przeszłości, stanowią istotny argument w dyskusji na temat unowocześniania polskiej pamięci. Wytwarzanie wspólnot pamięci lokalnej oraz wspólnot pamięci narodowej na mezo poziomie agregacji społecznej zasługuje - podkreślę to raz jeszcze - na wyjątkową uważność. Gdy się chce zdiagnozować polską pamięć, warto zajmować się Polską lokalną i właściwymi jej formami instytucjonalnymi. Trzeba - w moim przekonaniu - rekonstruować ich lepsze i gorsze zapisy badawcze, wiele bowiem mówią one o kompasach polskiej pamięci, o ich społecznym zakorzenieniu.

\section{Abstract}

\section{Joanna Kurczewska}

INSTITUTE OF PHILOSOPHY AND SOCIOLOGY OF THE POLISH ACADEMY OF SCIENCES

Communities of Local and National Memory: A Few Comments about Their Collective Formation à la Polonaise

Kurczewska explores how communities of local and national memory are formed. Working on the assumption that they are emotional communities, she diagnoses them from a socio-institutional perspective, drawing on numerous empirical studies on local communities and their basic collective agents, such as associations, clubs and other initiatives. She proposes that the years 1989-2015 (i.e. the Third Republic) saw the formation of communities of memory, which functioned on the meso level of Polish society. They shaped the content and forms of collective memory, becoming an essential social and cultural resource for Polish memory. Kurczewska points out that these communities are a necessary element to diagnose the national memory of Polish society as a complex structural entity. Last but not least, they are a factor in a'grassroots' social and cultural interpretation on the level of the macrosociety of the state.

\section{Keywords}

social memory, communities of local memory, communities of national memory, emotional community, civic society, institutions, organizations of commemoration 